\title{
Employees' Remuneration and Performance in Nigerian Breweries PLC
}

\author{
Ogunyemi Joseph Kayode \\ Department of Banking and Finance \\ Faculty of Social and Management Sciences \\ Adekunle Ajasin University, P.M.B O0I \\ Akungba Akoko, Ondo State, Nigeria \\ E-mail:jossykay2013@gmail.com \\ Adewole Joseph Adeyinka \\ Ph.D, Department of Banking and Finance \\ Faculty of Social and Management Sciences \\ Adekunle Ajasin University, P.M.B OOI \\ Akungba Akoko, Ondo State, Nigeria \\ E-mail:princeadeyinkaadewolej@gmail.com \\ Akinde John Abiodun \\ Department of Banking and Finance \\ Faculty of Social and Management Sciences \\ Adekunle Ajasin University, P.M.B OOI \\ Akungba Akoko, Ondo State, Nigeria
}

\begin{abstract}
This Study Aimed At Assessing The Effects Employees' Remunerations On Productivity In The In Nigerian Breweries Plc. This Study Was Guided by three research objectives namely; to identify and discuss various forms of remuneration package in use, to examine the effects of remuneration packages on employees performance and to establish the relationship between improved remuneration and productivity in the Nigeria breweries. The study used descriptive research design. The population of this study consists of all staff working at the Nigerian Breweries PLC Ibadan. Sample of one hundred and twenty respondents were selected. A structured questionnaire was used to collect data from the respondents. The descriptive statistics employed include; frequencies and percentage and the relationship between independent and dependent variables were established using Pearson Product Moment Correlation coefficient with the use of (SPSS). The findings were presented using tables and figures. From the findings in the Hypothesis, the $r=0.509^{*}$ was obtained. This is significant as the $p$-value greater than 0.05 . This shows that there was a significant relationship between remuneration packages' and employee performance. The findings also revealed that quick payment of remuneration has great influence on employees' productivity. The study concluded that remuneration package such as overtime, constant remuneration payment, promotes morale and increase team cohesion. From this finding, it was recommended that, organization should continue providing security benefits to all employees, as it will positively influence employee productivity and raise overall performance in the all sectors. The study also recommends that the organization should continue providing health protection benefits to its employees since it will help them create a sense of loyalty and encourage their productivity in the economic sector. Organizations, especially Breweries PLC should review the current retirement package since a good retirement package will attract and retain employees in the organization and also improve their productivity.
\end{abstract}

Keywords: Employees' Remuneration, Performance in Nigerian Breweries, PLC.

\section{Introduction}

Productivity is a relationship between outputs and inputs. It rises when an increase in output occurs with a less than proportionate increase in inputs, or when the same output is produced with fewer inputs (ILO, 2005). Productivity can also be considered in monetary terms. If the price received for an output rises with no increase in the cost of inputs, this is also seen as an increase in productivity. Productivity improvements can also be understood at different levels. The productivity of individuals may be reflected in employment rates, wage rates, stability of employment, job satisfaction or employability across jobs or industries. Productivity of enterprises, in addition to output per worker, may be measured in terms of market share and export 
performance. The benefits to societies from higher individual and enterprise productivity may be evident in increased competitiveness and employment or in a shift of employment from low to higher productivity sectors.

According to Mathis and John (2003), productivity is a measure of the quantity and quality of work done, considering the cost of the resources used. The more productive an organization, the better its competitive advantage, because the costs to produce its goods and services are lower. Better productivity does not necessarily mean more is produced; perhaps fewer people (or less money or time) was used to produce the same amount. McNamara (2003) further states that, results are usually the final and specific outputs desired from the employee. Results are often expressed as products or services for an internal or external customer, but not always. They may be in terms of financial accomplishments, impact on a community; and so whose results are expressed in terms of cost, quality, quantity or time. He further notes that measuring productivity involves determining the length of time that an average worker needs to generate a given level of production. You can also observe the amount of time that a group of employees spends on certain activities such as production, travel, or idle time spent waiting for materials or replacing broken equipment. The method can determine whether the employees are spending too much time away from production on other aspects of the job that can be controlled by the business.

Employee productivity may be hard to measure, but it has a direct bearing on a company's profits. An employer fills his staff with productivity in mind and can get a handle on a worker's capabilities during the initial job interview. However, there are several factors on the job that help maximize what an employee does on the job (Lake, 2000). Brady (2000) state that, perhaps none of the resources used for productivity in organizations are so closely scrutinized as the human resources. Many of the activities undertaken in an HR System are designed to affect individual or organizational productivity. Pay, appraisal systems, training, selection, job design and compensation are HR activities directly concerned with productivity.

Bernardin, (2007) continues to state that controlling labour costs and increasing productivity through the establishment of clearer linkages between pay and performance are considered to be key human resource management (HRM) component of competitive advantage. In addition, increased concerns over productivity and meeting customer ${ }^{\text {ee }}$ requirements have prompted renewed interest in methods designed to motivate employees to be more focused on meeting (or exceeding) customer requirements and increasing productivity. What better way to do this than by establishing a closer connection between meeting such requirements and compensation?

Numerous surveys and experience of HR professionals have shown that while employees are concerned about how to earn more pay and enjoy attractive conditions of service, employers on the other hand would be striving to cut costs so as to post impressive profit at the end of the accounting period (Milkovitch and Newman, 2004). Meanwhile, studies have shown that provision of motivators has been resulting in employees' increased interest in the job, enthusiasm and increased productivity at work and absence of motivators has been the other way round (Mathis and John, 2003). Research into employee benefits such as remunerations and organizational commitment is becoming more important because some researchers have examined the relationship between them (Christoph, 1996) and also the relationship between employee benefits, motivation and productivity (Hong, et al., 1995). There is however, still some debate over remunerations on whether they facilitate in employee productivity leading to organizational performance and do remunerations impact on an organization's ability to attract, retain and motivate employees leading to productivity and improved organizations' performance (Milkovitch and Newman, 2004).

The main objective of this study is to assess the employee remuneration and employee performance in Nigerian Breweries Plc. The specific objectives of the study are to identify and discuss various forms of remuneration package in use, to examine the effects of remuneration packages on employees performance, establish the relationship between improved remuneration and productivity in the Nigeria breweries

The Hypothesis is presented in a null form which states that there is no significant relationship between effect of remuneration package and employee performance. There is some debate over remunerations on whether they facilitate organizational performance and whether they impact on an organization's ability to attract, retain and motivate employees. Conventional wisdom also says that remunerations can affect recruitment and retention, but there is little research to support this conclusion. This statement indicates that there is a gap which has not been explored and therefore this study was undertaken to seek to establish whether remunerations really do have an effect on employee productivity and make appropriate recommendations on how to address the problem.

The researcher benefitted from the study as it added on to the growing body of knowledge on the roles of remuneration in organizations. The study will also act as a source of reference for further studies to be done on human resource in most organizations in Nigerian. Employees will also benefit much from this study. Employee remunerations being one of the huge components in determination of organization performance, most of the employees will use the recommendations given to enhance high level of cooperation in their various job groups. 
The study will also help the Government, private organisations and other employers with information which will help them come up with policies and legislations on the administration of employee remunerations. Future researchers will also benefit from this study because it will provide them with relevant information on the topic.

\section{Literature Review}

\section{Remuneration}

Maicibi (2005) defined remuneration as pay or reward given to individuals for work done. He further identified the indicators of remuneration include: basic salary, wages, health schemes, pension schemes, transport allowances overtime allowance and responsibility allowances. Remuneration can also be referred to as monetary or financial benefits in form of salaries, wages, bonuses, incentives, allowances and benefits that is accrued or given to an employee or group of employees by the employer (firm) as a result services rendered by the employee(s),commitment to the organization or reward for employment.

\section{Salaries and Wages}

Different definitions have been advanced on salaries and wages usually to show the differences that exist between both terms. Braton \& Gold, (2003) basic salary is a fixed periodical payment for non-manual employees usually expressed in annual terms, paid per month with generally no additions for productivity. Wage refers to payment to manual workers, always calculated on hourly or piece rates. Surbhi (2015) also defined salary as a fixed amount paid to the employees at regular intervals for their performance and productivity whereas wages are the hourly- based payment given to the labour for the amount of work finished in a day. He further argued that while Salaried persons are generally said to be doing "white collar office jobs" which implies that an individual is well educated, skilled and is employed with some firm and holds a good position in the society, whereas the waged person are said to be doing "blue collar labour job" which implies that an individual is engaged in the unskilled or semiskilled job and is drawing wages on a daily basis.

One purpose of a person as an employee of a company is to earn income in the form of wages or compensation. Received wages to meet basic needs such as food, clothing and housing. Every company in determining the amount of wages paid to the employee must be feasible, so that the lowest wage that is given to meet the needs of their life (Kanzunnudin, 2007). Agburu (2012) argued for the importance of salaries and wages in Nigeria, he stated that wages should not only be adequate but they must also show some element of equity, this is particularly true from the point of the employees. Anything short of a fair and equitable wage or reward can quickly at tract the wrath of employees in an economy such as Nigeria.

For many Nigerian employees, wages or salaries are highly critical issues. They are decisive because without them in sufficient quantities, life becomes extremely precarious for the worker and members of his/her family. As direct financial rewards, wages and salaries are the most emphasized by the employees, thus they sort of take a centre stage in the scheme of things as far as rewards for work is concerned.

\section{Bonuses and Incentives}

Investopedia (2016) defined bonus as an additional compensation given to an employee above his/her normal wage. A bonus can be used as a reward for achieving specific goals set by the company, or for dedication to the company. Heathfield (2016) bonus pay is compensation over and above the amount of pay specified as a base salary or hourly rate of pay. The base amount of compensation is specified in the employee offer letter, in the employee personnel file, or in a contract. Employers can distribute bonus pay randomly as the company can afford to pay a bonus, or the amount of the bonus pay can be specified bycontract. To Bardot(2014) a bonus is a payment which is backward-looking and usually discretionary or at least not expected from the employee(s). A decision is made to pay it to one, a group or all employees, based on criteria decided by management to reward past achievements, such as reaching a specific profit or some important milestones for the organization, or in a totally discretionary manner but defined an incentive as a plan which is forward-looking. Payment is tied to the achievement of specific objectives that have been pre-determined and communicated to the employees that are on the plan. The purpose of the incentive scheme is to influence behaviour to reach the objectives by providing an incentive to work towards the goals. she further stated that incentive can be paid in cash or in non-monetary award, for example some gifts or travel (especially for sales). The incentive plan is not discretionary: if the upfront, agreed objectives are reached, the payment or award is made.

Romanoff (2008) defined bonus as a single payment made at the end of the performance period typically a year to reward extraordinary effort or achievement while incentive is a tangible or intangible reward that is designed to motivate a person or group to behave in a certain way. He further stressed that incentives differ from bonuses in that incentives define both what needs to be accomplished, what the employee will receive in return for accomplishing it. As a result incentives have greater behavioral and motivational impact.

\section{Expectancy Theory}

The Expectancy Theory of Motivation provides an explanation of why individuals choose one behavioural option over others. The basic idea behind the theory is that people will be motivated because they believe that their decision will lead to their desired outcome (Redmond, 2010). Expectancy theory proposes that work motivation is dependent upon the perceived association between performance and outcomes and individuals modify their behaviour based on their calculation of anticipated outcomes (Torrington, 2009). This has a practical and positive benefit of improving motivation because it can, and has, helped 
leaders create motivational programs in the workplace. This theory is built upon the idea that motivation comes from a person believing they will get what they want in the form of performance or rewards. Although the theory is not all inclusive of individual motivation factors, it provides leaders with a foundation on which to build a better understanding of ways to motivate subordinates (AETC, 2008). Expectancy theory is classified as a process theory of motivation because it emphasizes individual perceptions of the environment and subsequent interactions arising as a consequence of personal expectations.

\section{The Total Reward Model}

Total reward describes a reward strategy that brings components such as learning and development together with aspects of the work environment, into the benefits package. In the total reward system both tangible and intangible rewards are considered valuable. Tangible rewards arise from transactions between the employer and employee and include rewards such as pay, personal bonuses and other benefits. Intangible rewards have to do with learning, development and work experience. Examples of these types of rewards are opportunity to develop, recognition from the employer and colleagues, personal achievement and social life. The aim of total reward is to maximize the positive impact that a wide range of rewards can have on motivation, job engagement and organizational commitments (Armstrong, 2006).

The purpose of total reward is to create a cluster where all the different reward processes are connected, complementary and mutually reinforcing each other. In order to achieve internal consistency, the total reward strategies are horizontally integ rated with human resource activities and vertically integrated with business strategies (Armstrong, 2006).

The benefits of a total reward system are described by Armstrong (2006) as: Greater impact when different types of rewards are combined, they will have a deep and long-lasting effect on the motivation, commitment and engagement of employees. Enhancing the employment relationship, total reward appeals more to employees due to the fact that it makes the maximum use of relational as well as transactional rewards. Enhancing cost-effectiveness because total reward communicates effectively the value of the whole reward package, it minimizes the undervaluing of the true costs of the packages. Flexibility to meet individual needs due to the variety of rewards, the total reward is able to answer the individual needs of the employees and hence bind them more strongly to the organization. Winning the war for talent because relational reward processes are more difficult to replace than individual pay practices, total reward gives the organization the ability to attract and retain talented employees by differentiating their recruitment process and hence becoming "a great place to work".

\section{Empirical Review}

Millea (2002) reports empirical evidence about the bi-directional relationship between employee's benefits and productivity, in particular considering the nature of the benefits setting process in different countries. The empirical evidence of this study as well as that of a more in-depth study for Germany (Millea, 2006) can be interpreted in the light of efficiency wages, i.e. explaining productivity as resulting from particular wage levels, for given characteristics of the labour market e.g. the total level of unemployment. Leaders should try to increase the belief that good performance will result in valued rewards. Ways of doing so include: measure job performance accurately; describe clearly the rewards that will result from successful performance; describe how the employee's rewards were based on past performance; provide examples of other employees whose good performance has resulted in higher rewards. In essence, leaders should link directly the specific performance they desire to the rewards desired by employees. It is important for employees to see clearly the reward process at work. Concrete acts must accompany statements of intent.

Compensation mechanisms can be a powerful incentive in linking performance to rewards. Compensation systems that reward people directly based on how well they perform their jobs are known as pay-for-performance plans (Berger, 2009). These may take such forms as "commission plans" used for sales personnel, "piece-rate systems" used for factory workers and field hands, and "incentive stock option (ISO) plans" for executives (Dunn, Mercer, Carpenter, \& Wyman, 20I0) and other employees (Baker, 2012). However, rewards linked to performance need not be monetary. Symbolic and verbal forms of recognition for good performance can be very effective as well (Markham, Dow, \& McKee, 2002).

Employee remuneration is not just about pay, for example, wages and salaries. It is also concerned with non-pay benefits or benefits in kind. These non-pay benefits are usually known as employee security benefits; and sometimes as 'perks'. On balance, the former refers to the more important benefits, such as pensions, and include those which are widely applied in the organization. The latter refer either to less significant benefits such as private health insurance, or to benefits provided primarily as a privilege (Cole, 2002). He continues by saying that the work related benefits are linked closely to the day-to-day operational requirements of the organization in relation to its members. Thus, employees need to be adequately nourished during the working day, properly trained to justify their responsibilities and provided with adequate means of transport when on the organization business.

According to the Employment Act of Kenya (2007), the law specifies normal number of working hours varied by industries. If an employee works in excess of normal hours per week as specified, the additional hours are treated as overtime. Therefore employees can be asked to work a reasonable amount of overtime to complete a job. However, union contracts often restrict the 
authority of employers regarding overtime. Also in some profession such as nursing an employee may be required to work overtime to save life.

According to the COR (2006), leave is granted for recuperative purposes to enable an officer renew his energies and improve efficiency. Leave is taken without loss of seniority or benefits but is subject to exigencies of service. In addition to normal full pay, an officer who takes a minimum of one-half of his annual leave entitlement will be eligible for leave allowance once a year, the rate of which is determined by the Government from time to time. Officers stationed in any designated hardship area may proceed on leave twice a year and is eligible for payments of leave allowance twice per year. Shellengarger (200I), states that employers give employees paid time off in a variety of circumstances. Paid lunch breaks and rest periods, holidays and vacations are common. But leaves are given for a number of other purposes as well. Time-off benefits represent an estimated 5\% to I3\% of total compensation. Typical time-off benefits include holiday pay, vacation pay and leaves of absence.

Baase (2009) states that evidence clearly shows that the health of the workforce is inextricably linked to the productivity of the workforce and the health of the nation's economy. It also shows that employers increasingly recognize this link and are interested in improving worker health by expanding workforce health protection and health promotion benefit programs. Also many employers allow employees to miss a limited number of days because of illness without losing pay. Some employers allow employees to accumulate unused sick leave, which may be used in case of catastrophic illnesses. Others pay employees for unused sick leave. Some organizations have shifted emphasis to reward people who do not use sick leave by giving them well-pay - extra pay for not taking sick leave (Mathis, 2003). Research also shows a much greater connection between employee health and productivity in the workplace than was ever realized in the past. For example, studies have shown that on average for every one dollar spent on worker medical/pharmacy costs, employers absorb two to three dollars of health-related productivity costs (Loeppke, 2009).

According to Collins et al (2005), research has shown that common chronic conditions, such as cancer, heart disease, and diabetes, are driving up total health-related costs in the workplace. Other health conditions among workers ranging from musculoskeletal/pain and depression are adding to those costs. In addition to a steadily rising medical and pharmaceutical cost burden, employers are now also seeing evidence of significant productivity cost impacts related to poor health. The workers compensation system requires employers to give cash benefits, medical care, and rehabilitation services to employees for injuries or illnesses occurring within the scope of their employment (Atkinson, 2009). In exchange employees give up the right of legal actions and awards. However, it is in the interests of both employers and employees to reduce workers ${ }^{\text {ee }}$ comp costs through safety and health programs (Pikiell, 2000).

Among the issues in the retention of older workers, it seems most important to first counter organizations se stereotypical notion that older workers are too costly and less productive than younger workers. Even when such skewed notions have been well countered with research evidence supporting the advantages to retaining older workers (Feinsod, 2006), there remain the challenges of how best to effectively retain/employ, manage, and enhance the productivity of an aging workforce. A study by the Tripartite Alliance for Fair Employment Practices (TAFEP) on generational issues in the Singapore workplaces has shown that a multi-generational workforce has many potential advantages and opportunities both for the individual and for the organization when effectively managed (TAFEP, 20I0). When agreeing to retain/employ older workers, employers should be open to the needs of older workers, which may involve improvement in management systems to meet workplace needs and may include the re-packaging of benefits and rewards to include flexible work arrangements, target hiring to focus on skills rather than age, phased retirement to allow for gradual exit from the workforce with re-employment, and the expansion of HR roles to include counseling of older workers to motivate them in continued employment.

According to Perrin. (2005), leading organizations, need to understand the current, and future, workforce composition and offer the right package of rewards and other programs to attract, retain and engage the people an organization needs. The opportunity also exists to align employee and customer demographics and to become a chosen employer for the multiple generations represented in today's workforce. However, whether any organization will be successful in retaining its baby boomer talent will depend on offering rewards that effectively meet the needs of older workers. Research shows these include competitive healthcare and retirement benefits as well as important intangibles like work-schedule and work-location flexibility and respect for employee contributions. Health-care and retirement benefits top the list of what 50-and-older workers at large companies look for in deciding whether to stay with an organization, although intangibles like work-life balance, the opportunity to work with high caliber colleagues and on-the-job recognition also play significant roles.

Auer and Fortuny (2000), state that while retirement policies constitute a "push" factor for non-employment of old-aged workers, pension systems and policies are a "pull” factor. It is well observed, especially in advanced European welfare countries that more generous pension benefits tend to pull old-aged workers out of employment even before normal retirement age but the availability of retirement funds to older workers contributes to the "pull factor" of retirement. A pessimistic view by BorschSupan (2003), an aging workforce driven by low fertility and longer life expectancy has negative effects on economic growth through a set of interrelated mechanisms: decreasing labour input due to low population growth and aging; decreasing rates of savings and capital accumulation due to increasing dependency ratios and the social cost of long-term care; decreasing investment 
in the human capital of the young generation due to increasing social welfare costs; lower level of innovation and renovation and/or dynamics.

But on the other hand, Scarth (2002), for example, asserts that that an aging workforce could lead to productivity growth by motivating "increased" investment in human capital as labour becomes a relatively scarce production factor.

Employee welfare has been defined by Mishra \& Bhagat (2007) as a state of well being, health, happiness, prosperity and the development of human resources which involves both the social and economic aspects. The social concept of welfare refers to the welfare of the average worker, his family and his community at large while the economic aspect of the welfare package covers promotion of economic development by increasing production and productivity. If an employee enjoys his time off, gets rest, eats well and takes care of himself, he will have more energy to devote to the job. A happy home life usually translates into a happy work life, and problems at the home front usually clock in when the worker does.

Abbasi (2000) continue to state that workers do pay attention to their co-workers, and discontent can spread rapidly among an organization if some employees are negative or don't do their fair share. On the other hand, an enthusiastic work crew that helps one another out can make even a seemingly dead-end job pleasurable. If the work crew has minimal turnover, this lets the worker know his job probably won't disappear overnight. The employee will also be more productive when she knows the job is doable with the tools the company gives her. This may mean office equipment that doesn't conk out during heavy periods, machinery that works well and procedures that are streamlined enough to get the job done without a lot of wasted effort.

A growing number of organizations offer awards to employees for extended service, work-related achievements and suggestions for improving organizational effectiveness. Awards are often in the form of gifts and travel rather than cash. Suggestion systems offer incentives to employees who submit ideas that result in greater efficiency or profitability for the company (Bernardin, 2007).

Sajuyigbe, Olaoye and Adeyemi (2013) conducted research work on impact of Reward on Employees Performance in a Selected Manufacturing Companies in Ibadan, Oyo State, Nigeria. Human resource is one of the important assets that organization owns. Reward helps management to retain efficient and experienced workforce in an organization. The objective was to examine the impact of reward on employees' performance with special reference to selected manufacturing companies in Ibadan, Oyo State, Nigeria. Structured questionnaire was used to collect data from one hundred (IO0) participants through purposive sampling method and data were analyzed by multiple regression analysis with the aid of statistical package for social science (SPSS) version I6. Result showed that reward dimensions jointly predict employees' performance, which accounted for 7I\% variance of performance. Subsequently, recommendations were made to the management of organizations that they should buildup the commitment among employees by rewards and achieve both individual and Organizational objectives. However, the study is relevant to this study which examines employee remuneration and employee performance in Nigeria Breweries Plc.

Oloke, Oni, Babalola, and Ojelabi 2017 conducted research on Incentive Package, Employee's Productivity and Performance of Real Estate Firms in Nigeria. The level of motivation received by an employee as reflected in the satisfaction with the base pay package and other incentives goes a long way to influencing the employees' attitude to work, loyalty, performance and job satisfaction. Employee's motivation and organization performance has been investigated across different fields and economic sectors. This study takes it further by examining incentive package, employees and organization productivity in real estate firms in Nigeria. Panel survey approach was adopted and three questionnaires administered in each of the one hundred and seventeen (II7) estate firms in Ikeja, Victoria Island and Lekki Area of Lagos State. Respondents were two employees and one other in employers'/management capacity. Descriptive tools such as frequency and percentage were used to identify and determine the proportion of firms that make use of incentive package/option while a 5-point Likert scale and ranking were used to determine and rank the options in order of importance among these firms. Panel data regression model was used to determine the strength of relationship between firms' performance/productivity and incentives whilst holding other factors constant. Findings showed amongst others that there is strong positive correlation between incentive and employee productivity, employees are largely dissatisfied with the incentives offered by majority of estate firms and that incentive package is not the most important determinants of performance in real estate firms. The study therefore concludes that employers in real estate firms pay attention to other factors identified and review remuneration and incentive package to boost the morale of their employees for better performance.

Agba, A. M. O, Mboto, W. A. and Agba, M. S. (2013) research on Wages or Other Conditions: A Critical Assessment of Factors in Workers Performance in Nigeria the challenge of getting maximum performance from employees remain a perennial problem to managers in Nigeria. This challenge is aggravated by the great divide that exist among managers on which of the motivational factors stimulate workers the more into higher performance; while some tilt to monetary incentives; many more argue that non-monetary incentives are major motivating factors. Thus, this study is set to investigate factors that influence workers' job performance in Nigeria. The study attempt to compare the influence of wages and other conditions service on employees' performance. To achieve this objective, we elicited information from 300 respondents who were purposively sample from four organizations in some selected geo-political zones in Nigeria. Data collected were presented in graph, pie chart and bar chart. Findings reveal that, employee job performance are greatly influenced by regular and good wages; followed by 
conducive work environment, availability of internet facilities, good library, recognition/award, regular promotion, training opportunities, access to medical care and communication flow. We made the following recommendations among others, that managers of formal organizations should properly remunerate workers as well as provide conducive work environment for their employees. We posit that other least motivating factors as identified in this study should not ignore by managers, since each provide workers with a level of stimulant that propel them into maximum performance in work organization.

Abdulkadir M. D, Mohamed M. J, Ali Yassin S. A ( 2015) conducted research on Employee motivation and organizational performance: empirical evidence from secondary schools in Mogadishu-Somalia This paper attempts to identify the impact of motivation on employee performance in order to address problems arising from motivational approaches in organizational settings in Mogadishu, Somalia. The paper had three main objectives which are: I) To identify the relationship between work environment and organizational performance at secondary schools in Mogadishu. 2) To examine the relationship between cooperation and organizational performance secondary schools in Mogadishu, Somalia. 3) To explore the relationship between facilitation and organizational performance secondary schools in Mogadishu-Somalia. The researchers utilized convenient sampling to collect 100 questionnaires from twelve secondary schools in Mogadishu, Somalia. Employees of these schools provided a questionnaire with four main construct which measuring work environment, cooperation, facilitation and organizational performance. However, using correlation coefficient, the study found that organizational performance (Dependent variable) had significant positive influence with two independent variables namely, work environment, and facilitation. Also, the result of regression analysis found that two constructs had statistically significant, positive, and direct effects on the organizational performance. Finally, regarding these two hypotheses; this study supported; the most indicator of employee motivation was facilitation; the employees like the managers who motivate them in the workforce.

\section{Methods}

\section{Population of the Study}

Population of the study refers to the totality of the objects or elements being studied and which the conclusion or generalization of our result will apply or group of people or items about which we want to obtain information. It is also being described as a sum total of all the units of analysis that constitute the focus of study.

The population of the study comprises of all staff working under the Nigerian Breweries PLC. This population extends beyond the shores of south western Nigeria. As such, all staff of the Nigerian Breweries PLC in the six geo-political zones of the country made up the population.

\section{Sample Size and Sampling Technique}

The sample size was drawn from the population of staff of the Nigerian Breweries PLC in which, I20 staffs in the Ibadan, South-western part of Nigeria was selected and purposive sampling technique was adopted in selecting samples from the population for the purpose of the study. This sampling technique was adopted so as to ensure that only respondents that are of equal significance to the study were selected. Thus, their responses are bound to be reliable and maybe used for generalization.

\section{Sources of Data Collection}

The data for the study will be obtained from two sources, which are primary and secondary sources. Both sources were explored in order to get comprehensive and adequate information needed for the research work, which eventually assisted in providing platforms for accurate recommendation for the study.

\section{Primary Sources}

The primary data is the one which raw information is collected by the user from specific place, which in the case of Nigerian Breweries PLC. This source is usually explored at the actual time in which required information is needed. It enables the researcher have direct contact with the object, with the view to gather correct information. The primary data for this study was collected through the administer of questionnaire.

\section{Secondary Sources}

This is the kind of information gathered by someone else for some purposes, which another person can use during the cause of carrying out research work. This method is always used to compliment the primary data. The secondary data for this study were obtained from textbooks, newspapers, journals websites etc.

\section{Instrumentality}

A questionnaire is a designed form which consists of a set questions sent to people (respondents) for completion, to gather information for analysis and to confirm relevant research questions which are later returned for analysis.

\section{Questionnaire Design and Arrangement}

The questionnaire employed for this study consists of two (2) section "A" and "B". Section "A" has to do with the socioeconomic characteristics of the workers of Nigerian Breweries PLC and it contains six (6) questions while section "B” contain s 
twenty (20) major questions. Each question has options from which respondents were to make choices. The options available for the respondents include; Strongly Agreed (SA), Agreed (A), Undecided (U), Disagreed (D), and Strongly Disagreed (SD). This is expected to help the researcher to understand the level of maturity of the respondents which goes a long way in affecting their responses that will be gathered through questionnaire.

\section{Method of Data Analysis}

In this research work, simple regression analysis method were used with the aid of Statistical Package for Social Science (SPSS) from the primary data collected in the field using frequency counts and simple percentage.

\section{Results}

This section deals with the analysis of data analysis and presentation of results. A questionnaire was designed for the collection of the data. The analysis of the report on demographic information was first given with the distribution of respondents according to sex, marital status, age and educational qualification. The second section deals with hypothesis testing.

\section{Section A: Bio-Data}

Table I: Distribution of respondents by sex

\begin{tabular}{lll}
\hline Sex & Frequency & Percentage \\
\hline Male & 66 & 55.0 \\
\hline Female & 54 & 45.0 \\
\hline Total & I20 & 100.0 \\
\hline
\end{tabular}

Sources: Researcher's field survey, 2018

The table above indicated the distribution of the respondents by their gender in the study area. This implies that $66(55.0 \%)$ respondents were male in the study area, while $54(45.0 \%)$ of the respondents were female in the study area.

Table 2: Distribution of respondents by marital status

\begin{tabular}{lll}
\hline Marital Status & Frequency & Percentage \\
\hline Single & 56 & 46.7 \\
\hline Married & 59 & 49.2 \\
\hline Divorced & 5 & 4.2 \\
\hline Total & I20 & 100.0 \\
\hline
\end{tabular}

Sources: Researcher's field survey, 2018

The table above indicated the distribution of the respondents by their marital status. 56(46.7\%) respondents were single, $59(49.2 \%)$ respondents were married, while 5(4.2\%) respondents were divorced.

Table 3: Distribution of respondents by age

\begin{tabular}{lll}
\hline Age & Frequency & Percentage \\
\hline 2I-30 years & 39 & 32.5 \\
\hline 3I-40 years & 62 & $5 \mathrm{I.7}$ \\
\hline 4I-50 years & $\mathrm{I} 8$ & $\mathrm{I} 5.0$ \\
\hline 5I-60 years & $\mathrm{I}$ & .8 \\
\hline Total & $\mathrm{I} 20$ & $\mathrm{I00.0}$ \\
\hline
\end{tabular}

\section{Sources: Researcher's field survey, 2018}

Table 3 revealed the distribution of the respondents by their age in the study area. This implies that 39(32.5\%) respondents were between the ages of 2I-30 years, 62(5I.7\%) respondents were between the ages of 3I-40 years, I8(I5.0\%) were between the ages of $4 \mathrm{I}-50$ years, $\mathrm{I}(0.8 \%)$ was between the ages of $5 \mathrm{I}-60$ years. 
Table 4: Distribution of respondents by position/status

\begin{tabular}{lcc}
\hline Position/Status & Frequency & Percentage \\
\hline Top Level Management & $2 \mathrm{I}$ & 17.5 \\
\hline Middle Level Management & 72 & 60.0 \\
\hline Lower Level Management & 27 & 22.5 \\
\hline Total & 120 & 100.0 \\
\hline
\end{tabular}

Sources: Researcher's field survey, 2018

The table above indicated the distribution of the respondent by their position/status. $2 \mathrm{I}(\mathrm{I} 7.5 \%)$ respondents were in top level management, $72(60.0 \%)$ respondents were in middle level management, while $27(22.5 \%)$ respondents were in lower level management.

Table 5: Distribution of respondents by educational qualification

\begin{tabular}{lll}
\hline Educational Qualification & Frequency & Percentage \\
\hline SSCE/O' Level & 5 & 4.2 \\
\hline ND/NCE & $2 \mathrm{I}$ & $\mathrm{I}$ \\
\hline HND/B. Sc & 46 & 38.5 \\
\hline MBA/M. Sc/ICAN/CIBN and others & 48 & 40.0 \\
\hline Total & $\mathrm{I} 20$ & 100.0 \\
\hline
\end{tabular}

Sources: Researcher's field survey, 2018

The table above indicated the distribution of the respondents by their educational qualification. $5(4.2 \%)$ respondents had SSCE/O' Level certificates, 2I(I7.5\%) respondents had ND/NCE certificates, 46(38.3\%) respondents had HND/B. Sc certificates, while $48(40.0 \%)$ respondents had MBA/M. Sc/ICAN/CIBN and other certificates.

Table 6: Distribution of respondents by number of years in service

\begin{tabular}{lll}
\hline Years in Service & Frequency & Percentage \\
\hline I-5 years & 58 & 48.3 \\
\hline 6-I0 years & 47 & 39.2 \\
\hline II-20 years & I I & 9.2 \\
\hline 2I-30 years & 2 & 1.7 \\
\hline 3I years and above & 2 & I.7 \\
\hline Total & I20 & I00.0 \\
\hline
\end{tabular}

Sources: Researcher's field survey, 2018

The table above indicated the distribution of the respondents by their number of years in service. 58(48.3\%) respondents had put in between I-5 years of service, 47(39.2\%) respondents had put in between 6-I0 years of service, II( $9.2 \%)$ respondents had put in between II-20 years of service, 2(I.7\%) respondents had put in between 2I-30 years of service, while 2(I.7\%) respondents had put in about $3 \mathrm{I}$ years and above.

\section{Section B: Forms of Remuneration Package}

Table 7: Security remuneration

\begin{tabular}{lll}
\hline & Frequency & Percentage \\
\hline Always & 58 & 48.3 \\
\hline Occasionally & 37 & 30.8 \\
\hline Sometimes & 22 & 18.3 \\
\hline Never & 3 & 2.5 \\
\hline Total & I20 & I00.0 \\
\hline
\end{tabular}

Sources: Researcher's field survey, 2018 
The table above indicates that 58(48.3\%) respondents are paid security remuneration always, $37(30.8 \%)$ respondents are paid occasionally, and 22 (I8.3\%) respondents are paid sometimes while $3(2.5 \%)$ respondents have never been paid security remunerations.

Table 8: Overtime

\begin{tabular}{lll}
\hline & Frequency & Percentage \\
\hline Always & II & 9.2 \\
\hline Occasionally & 47 & 39.2 \\
\hline Sometimes & 53 & 44.2 \\
\hline Never & 9 & 7.5 \\
\hline Total & I20 & I00.0 \\
\hline
\end{tabular}

Sources: Researcher's field survey, 2018

The table above indicates that $\mathrm{II}(9.2 \%)$ respondents are paid overtime always, $47(39.2 \%)$ respondents are paid overtime occasionally, and $53(44.2 \%)$ respondents are paid overtime sometimes while $9(7.5 \%)$ respondents have never been paid overtime.

Table 9: Annual leave

\begin{tabular}{lll}
\hline & Frequency & Percentage \\
\hline Always & 36 & 30.0 \\
\hline Occasionally & 53 & 44.2 \\
\hline Sometimes & 26 & 21.7 \\
\hline Never & 5 & 4.2 \\
\hline Total & I20 & I00.0 \\
\hline
\end{tabular}

Sources: Researcher's field survey, 2018

The table above indicates that 36(30.0\%) respondents always take annual leave, 53(44.2\%) respondents take annual leave occasionally, and $26(21.7 \%)$ respondents take annual leave sometimes while $5(4.2 \%)$ respondents have never taken annual leave.

Table 10: Maternity leave

\begin{tabular}{lll}
\hline & Frequency & Percentage \\
\hline Always & 26 & 21.7 \\
\hline Occasionally & 36 & 30.0 \\
\hline Sometimes & 9 & 7.5 \\
\hline Never & 49 & 40.8 \\
\hline Total & I20 & 100.0 \\
\hline
\end{tabular}

Sources: Researcher's field survey, 2018

The table above indicates that 26(21.7\%) respondents always get maternity leave, $36(30.0 \%)$ occasionally get maternity leave, $9(7.5 \%)$ sometimes get maternity leave while a whopping $49(40.8 \%)$ respondents never get maternity leave.

Table II: Education and house allowance

\begin{tabular}{lll}
\hline & Frequency & Percentage \\
\hline Always & 40 & 33.3 \\
\hline Occasionally & 39 & 32.5 \\
\hline Sometimes & 34 & 28.3 \\
\hline Never & 7 & 5.8 \\
\hline Total & I20 & 100.0 \\
\hline
\end{tabular}

\section{Sources: Researcher's field survey, 2018}

The table above indicates that 40(33.3\%) respondents always get education and house allowance, 39(32.5\%) respondents occasionally get education and house allowance, $34(28.3 \%)$ respondents sometimes get education and house allowance while $7(5.8 \%)$ respondents never get education and house allowance 
Table I2: Health protection

\begin{tabular}{lll}
\hline & Frequency & Percentage \\
\hline Always & 70 & 58.3 \\
\hline Occasionally & 26 & 21.7 \\
\hline Sometimes & 20 & 16.7 \\
\hline Never & 4 & 3.3 \\
\hline Total & $\mathrm{I} 20$ & 100.0 \\
\hline
\end{tabular}

Sources: Researcher's field survey, 2018

The table above indicates that $70(58.3 \%)$ respondents get health protection always, $26(21.7 \%)$ respondents occasionally get health protection, 20(16.7\%) respondents sometimes get health protection and $4(3.3 \%)$ respondents never get health protection.

\section{Table 13: Personnel recognition}

\begin{tabular}{lll}
\hline & Frequency & Percentage \\
\hline Always & 54 & 45.0 \\
\hline Occasionally & 44 & 36.7 \\
\hline Sometimes & 19 & 15.8 \\
\hline Never & 3 & 2.5 \\
\hline Total & I20 & 100.0 \\
\hline
\end{tabular}

Sources: Researcher's field survey, 2018

The table above indicates that 54(45.0\%) respondents get personnel recognition always, 44(36.7\%) respondents occasionally get personnel recognition, I9(15.8\%) get personnel recognition sometimes and $3(2.5 \%)$ respondents never get personnel recognition.

Section C: Effect of Remuneration Package on Employees' Performance

Table 14: Constant remuneration payment enhances employees' performance

\begin{tabular}{lll}
\hline & Frequency & Percentage \\
\hline Strongly agree & 40 & 33.3 \\
\hline Agree & 69 & 57.5 \\
\hline Neutral & 5 & 4.2 \\
\hline Disagree & 5 & 4.2 \\
\hline Strongly disagree & I & .8 \\
\hline Total & I 20 & I00.0 \\
\hline
\end{tabular}

Sources: Researcher's field survey, 2018

The table above indicates that $40(33.3 \%)$ strongly agree that constant remuneration enhances employees' performance, $69(57.5 \%)$ respondents agree with the statement, 5(4.2\%) respondents are neutral, $5(4.2 \%)$ respondents disagree with the statement and $\mathrm{I}(0.8 \%)$ respondent strongly disagrees with the statement.

Table 15: Overtime remuneration can be effective in long-term motivation and productivity

\begin{tabular}{lll}
\hline & Frequency & Percentage \\
\hline Strongly agree & 23 & 19.2 \\
\hline Agree & 64 & 53.3 \\
\hline Neutral & 19 & 15.8 \\
\hline Disagree & 13 & 10.8 \\
\hline Strongly disagree & I & .8 \\
\hline Total & I20 & I00.0 \\
\hline
\end{tabular}

Sources: Researcher's field survey, 2018

The table above indicates that $23(19.2 \%)$ respondents strongly agree that overtime remuneration can be effective in long-term motivation and productivity, 64(53.3\%) respondents agree with the statement, I9(I5.8\%) respondents are neutral, I3(I0.8\%) respondents disagree with the statement, $\mathrm{I}(0.8 \%)$ respondent strongly disagrees with the statement. 
Table 16: Pooling employees in a team with collective goal increases productivity if you provide worthwhile remuneration

\begin{tabular}{lll}
\hline & Frequency & Percentage \\
\hline Strongly agree & 22 & I8.3 \\
\hline Agree & 84 & 70.0 \\
\hline Neutral & 8 & 6.7 \\
\hline Disagree & 6 & 5.0 \\
\hline Total & I20 & I00.0 \\
\hline
\end{tabular}

Sources: Researcher's field survey, 2018

The table above indicates that $22(\mathrm{I} 8.3 \%)$ respondents strongly agree that pooling employees in a team with collective goal increases productivity if you provide worthwhile remuneration, $84(70.0 \%)$ respondents agree with the statement, $8(6.7 \%)$ respondents are neutral and $6(5.0 \%)$ respondents disagree with the statement.

Table 17: Employee morale improves if each one of them is granted opportunities to reach a set of goals

\begin{tabular}{lll}
\hline & Frequency & Percentage \\
\hline Strongly agree & 33 & 27.5 \\
\hline Agree & 69 & 57.5 \\
\hline Neutral & I I & 9.2 \\
\hline Disagree & 7 & 5.8 \\
\hline Total & I20 & 100.0 \\
\hline
\end{tabular}

Sources: Researcher's field survey, 2018

The table above indicates that $33(27.5 \%)$ respondents strongly agree that employee morale improves if each one of them is granted opportunities to reach a set of goals, $69(57.5 \%)$ respondents agree with the statement, II $(9.2 \%)$ respondents are neutral and $7(5.8 \%)$ respondents disagree with the statement.

Table 18: Remuneration promotes morale and increases team cohesion

\begin{tabular}{lll}
\hline & Frequency & Percentage \\
\hline Strongly agree & 27 & 22.5 \\
\hline Agree & 59 & 49.2 \\
\hline Neutral & 8 & 6.7 \\
\hline Disagree & 24 & 20.0 \\
\hline Strongly disagree & 2 & 1.7 \\
\hline Total & 120 & 100.0 \\
\hline
\end{tabular}

Sources: Researcher's field survey, 2018

The table above indicates that $27(22.5 \%)$ respondents agree that remuneration promotes morale and increases team cohesion, $59(49.2 \%)$ respondents agree with the statement, $8(6.7 \%)$ respondents are neutral, $24(20.0 \%)$ respondents disagree with the statement and $2(1.7 \%)$ respondents strongly disagree with the statement.

Section D: Relationship between Improved Remuneration and Productivity in Nigeria

Table 19: High remuneration is capable of increasing the self-confidence of employees

\begin{tabular}{lll}
\hline & Frequency & Percentage \\
\hline Strongly agree & $3 \mathrm{I}$ & 25.8 \\
\hline Agree & 45 & 37.5 \\
\hline Neutral & $2 \mathrm{I}$ & $\mathrm{I}$ \\
\hline Disagree & 23.5 & 19.2 \\
\hline Total & $\mathrm{I} 20$ & 100.0 \\
\hline
\end{tabular}

Sources: Researcher's field survey, 2018

The table above indicates that $3 \mathrm{I}(25.8 \%)$ strongly agree that high remuneration is capable of increasing the self confidence of employees, $45(37.5 \%)$ respondents agree with the statement, $2 \mathrm{I}(\mathrm{I} 7.5 \%)$ respondents are neutral, 23(I9.2\%) respondents disagree with the statement. 
Table 20: To motivate employees through remuneration, it is necessary that remuneration is equitable and externally competitive

\begin{tabular}{lll}
\hline & Frequency & Percentage \\
\hline Strongly agree & 22 & I8.3 \\
\hline Agree & 78 & 65.0 \\
\hline Neutral & I I & 9.2 \\
\hline Disagree & 9 & 7.5 \\
\hline Total & I20 & I00.0 \\
\hline
\end{tabular}

Sources: Researcher's field survey, 2018

The table above indicates that $22(18.3 \%)$ respondents strongly agree that to motivate employees through remuneration, it is necessary that remuneration is equitable and externally competitive, $78(65.0 \%)$ respondents agree with the statement, $\mathrm{II}(9.2 \%)$ respondents are neutral, and $9(7.5 \%)$ respondents disagree with the statement.

Table 2I: Employee remuneration package is a more efficient motivating factor as it can easily increase according to the proportion of work

\begin{tabular}{lll}
\hline & Frequency & Percentage \\
\hline Strongly agree & 30 & 25.0 \\
\hline Agree & 72 & 60.0 \\
\hline Neutral & $\mathrm{I3}$ & $\mathrm{I0.8}$ \\
\hline Disagree & 5 & 4.2 \\
\hline Total & $\mathrm{I} 20$ & 100.0 \\
\hline
\end{tabular}

Sources: Researcher's field survey, 2018

The table above indicates that $30(25.0 \%)$ respondents agree that employee remuneration package is a more efficient motivating factor as it can easily increase according to the proportion of work, $72(60.0 \%)$ respondents agree with the statement, I3(I0.8\%) respondents are neutral and 5(4.2\%) respondents disagree with the statement.

Table 22: Quick payment of remuneration is assumed to greatly influence employee productivity

\begin{tabular}{lll}
\hline & Frequency & Percentage \\
\hline Strongly agree & 39 & 32.5 \\
\hline Agree & 64 & 53.3 \\
\hline Neutral & 8 & 6.7 \\
\hline Disagree & 5 & 4.2 \\
\hline Strongly disagree & 4 & 3.3 \\
\hline Total & I20 & 100.0 \\
\hline
\end{tabular}

Sources: Researcher's field survey, 2018

The table above indicates that $39(32.5 \%)$ respondents strongly agree that quick payment of remuneration is assumed to greatly influence employee productivity, 64(53.3\%) respondents agree with the statement, $8(6.7 \%)$ respondents are neutral, 5(4.2\%) respondents disagree with the statement, $4(3.3 \%)$ respondents strongly disagree with the statement

Table 23: Enticing remuneration package increases employee dedication and improved productivity

\begin{tabular}{lll}
\hline & Frequency & Percentage \\
\hline Strongly agree & 32 & 26.7 \\
\hline Agree & 52 & 43.3 \\
\hline Neutral & $\mathrm{I} 9$ & $\mathrm{I} 5.8$ \\
\hline Disagree & $\mathrm{I3}$ & $\mathrm{I} 0.8$ \\
\hline Strongly disagree & 4 & 3.3 \\
\hline Total & $\mathrm{I} 20$ & $\mathrm{I}$ \\
\hline
\end{tabular}

Sources: Researcher's field survey, 2018

The table above indicates that $32(26.7 \%)$ respondents agree that enticing remuneration package increases employee dedication and increased productivity, 52(43.3\%) respondents agree with the statement, I9(15.8\%) respondents are neutral, I3(I0.8\%) respondents disagree with the statement and $4(3.3 \%)$ respondents strongly disagreed with the statement. 
Table 24: The type of remuneration and fringe benefit made available to employees greatly determines how motivated they would be committed to duties

\begin{tabular}{|c|c|c|}
\hline & Frequency & Percentage \\
\hline Strongly agree & 38 & 31.7 \\
\hline Agree & 65 & 54.2 \\
\hline Neutral & 8 & 6.7 \\
\hline Disagree & 5 & 4.2 \\
\hline Strongly disagree & 4 & 3.3 \\
\hline Total & 120 & 100.0 \\
\hline
\end{tabular}

Sources: Researcher's field survey, 2018

The table above indicates that $38(31.7 \%)$ respondents strongly agree that the type of remuneration and fringe benefit made available to employees greatly determines how motivated they would be committed to duties, $65(54.2 \%)$ respondents agree with the statement, $8(6.7 \%)$ respondents are neutral, $5(4.2 \%)$ respondents disagree with the statement, $4(3.3 \%)$ respondents strongly disagree with the statement.

Table 25: For remuneration scheme to achieve desired objective, which is employee productivity, its implementation must not frustrate the employee

\begin{tabular}{|c|c|c|}
\hline & Frequency & Percentage \\
\hline Strongly agree & 62 & 51.7 \\
\hline Agree & 45 & 37.5 \\
\hline Neutral & 9 & 7.5 \\
\hline Disagree & 2 & 1.7 \\
\hline Strongly disagree & 2 & 1.7 \\
\hline Total & 120 & 100.0 \\
\hline
\end{tabular}

Sources: Researcher's field survey, 2018

The table above indicates that $62(51.7 \%)$ strongly agree that for remuneration scheme to achieve desired objective, which is employee productivity, its implementation must not frustrate the employee, $45(37.5 \%)$ respondents agree with the statement, $9(7.5 \%)$ respondents are neutral, $2(1.7 \%)$ respondents disagree with the statement and $2(1.7 \%)$ strongly disagree with the statement.

\section{Testing of Hypothesis}

Hypothesis I: There is no significant relationship between effect of remuneration package and employee performance.

Table 26

Relationship between effect of remuneration package and employee performance.

\begin{tabular}{|c|c|c|c|c|c|c|c|c|}
\hline Variables & $\mathrm{N}$ & $\bar{X}$ & $\mathrm{SD}$ & & $\mathrm{P}$ & Df & r.cal. & r.tab. \\
\hline $\begin{array}{l}\text { Effect of remuneration } \\
\text { package }\end{array}$ & & 24.6333 & & 4.18065 & & & & \\
\hline & 120 & & & & 0.05 & II8 & $.509^{\text {sta }}$ & 0.195 \\
\hline $\begin{array}{l}\text { Remuneration } \\
\text { Productivity }\end{array}$ & & I4.0083 & & 3.23452 & & & & \\
\hline
\end{tabular}

Table 26 shows that there is a significant relationship between effect of remuneration package and employee performance. The calculated r. value 0.509 is greater than the table value 0.195 at 0.05 level of significance. The hypothesis is therefore rejected. This implied that there was a significant relationship between effect of remuneration package and employee performance.

5. Conclusion

This study has examined employees remunerations and employee performance in Nigerian Breweries PLC. In the course of this, it has reviewed relevant literature to show different views of remuneration in an organization.

An organization exists to provide goods and services that people desire. These goods and services are the products of the behaviours of workers who occupy different levels of the organizational structure. These people have different cultures, skills and educational background, as well as different perceptions, roles, expectations and values. 
The study concluded that remuneration package such as overtime, constant remuneration promotes morale and increase team cohesion. There was a significant relationship between effect of remuneration package and employee performance.

\section{Recommendations}

Having analyzed, discussed and interpreted the data collected for this study, it is imperative to make certain recommendation that could to improve employees remunerations on productivity. Therefore, the following recommendations are essential:

- The study recommends that both public and private organisation should continue providing security benefits to all employee, as it will positively influence employee productivity and raise overall performance in the all sectors.

- The study also recommends that the organisation should continue providing health protection benefits to its employees since it will help them create a sense of loyalty and encourage their productivity in the public sector.

- The study continues to recommend that the organization especially Breweries Plc should review the current retirement package since a good retirement package will attract and retain employees in the public sector and also improve their productivity.

- organizations need to improvise employee recognition programme for jobs well done, this will motivate employees thus enhancing employee productivity in the private and public sectors.

- Organization had to formulate policies and procedures which ensured that both occupational health and safety and the medical insurance were guaranteed to employees.

\section{References}

Abbasi, S. \& Hollman, K. (2000). Turnover: The Real Bottom-line. Public Personnel Management, 29(3), 333-342.

Abdulkadir M. D, Mohamed M. J, Ali Yassin S. A ( 2015) Employee motivation and organizational performance: empirical evidence from secondary schools in Mogadishu-Somalia Afro Asian Journal of Social Sciences 8 (2), pp I-I6

Agba, A. M. O, Mboto, W. A. and Agba, M. S. (2013) Wages or Other Conditions: A Critical Assessment of Factors in Workers Performance in Nigeria International Journal of Academic Research in Business and Social Sciences, 3(7) pp489-505.

Agburu, J.I (2012). Recent Trends in Wage and Salary Administration in Nigeria: A Synopsis on Theoretical and Empirical Challenges. International Journal of Basic And Applied Science; I(2), 257-268

Allis, Ryan P. (2008). Zero to One Million (Ist edn): McGraw-Hills.

Andrews, Sudhir (2009). Human Resource Management: A Textbook for Hospitality Industry. Tata McGraw Hill.

Armstrong, M. \& Brown, D. (200I). New Dimensions in Pay Management, Chartered Institute of Personnel and Development.

Atkinson William, (2000). Is Worker"s Comp Changing? HR Magazine. July, 50-6I.

Auer, P., and Fortuny, M. (2000). Aging of the Labour Force in OECD Countries: Economic and Social Consequences. Employment Paper 2000/2. International Labour Office.

Baase, C.M.D., (2009). Testimony before the Senate Committee on Health, Education, Labor and Pensions 23.

Baker D (2012), „Why has the British. National Minimum Wage had little or no Impact on Employment? Journal of Industrial Relations, 50, 489-512.

Bardot, S. (2014). What is the difference between a bonus and an incentive? Retrieved on 25th August, 2017 http://compensationinsider.com/what-is-the-difference-between-a-bonusand-an-incentive.

Berger G, (2009), Labour Economics, Fifth International Edition, McGraw Hill.

Bernardin, H. J. (2007). Human Resource Management. An Experiential Approach. Tata McGraw Hill.

Bernardin, H. J. (2007). Human Resource Management. An Experiential Approach. Tata McGraw Hill.

Bernthal, Paul R. and Wellins, Richard S. (200I). Retaining Talent. A Benchmarking Study (Pittsburgh, PA: Development Dimensions International).

Borsch-Supan, Axel., (2003). Labor Market Effects of Population Aging. Review of Labour Economics and Industrial Relations, I7, 5-44.

Brady, M. (2000). Employee Work Engagement: Best Practices For Employers. Research Works: Partnership for Workplace Mental Health, I, I-I I.

Bratton, John and Gold, Jeff, (2009). Human Resource Management Theory and Practice (4th ed). Palgrave Macmillan. New York.

Christoph, N., \& Meyer, J. (1996). The measurement of antecedents of affective, Continuance and normative commitment to the organization. Journal of Occupational Psychology. 63, I-I8.

Code of Regulations for Civil Servant Revised (2006)

Cole, G. A (2002). Personnel \& Human Resource Management (5th ed). Letts Educational: London.

Collins J.J., Baase C., Sharda C.,(2005). The assessment of chronic health conditions on work performance, absence, and total economic impact for employers. J Occup Environ Med. 2(I) 28-36 
Deci, E. L. (1985). Effects of externally mediated rewards on intrinsic motivation. Journal of Personality and Social Psychology, I8, I05-II5.

Dunn, Mercer, Carpenter \& Wyman, (2010), „Employment and productivity: Is there a trade-off and does it matter? European Employment Observatory, Thematic expert ad-hoc paper, mimeo, IES.

Feinsod, R. and Davenport, T. (2006). The Aging Workforce: Challenge or Opportunity? World at Work.

Gostick, A., (2000). "They Do Recognition Right”, Workspan. October, 34-36.

Harris, J. (2000). Finding and Keeping Great Employees: Training.

Heathfield,S.M.(20I6).Bonus Pay. Retrieved from https://www.thebalance.com/what-is-bonus-pay-1918069

Hong, J. C., Yang, S. D., Wang, L. J., Chiou, E. F., Sun, F. Y., \& Huang, T. L. (I995). Impact of employee benefits on work motivation and productivity. The International Journal of Career Management. 7(6), I0-I4.

International Labour Organization (2005). Number of Work Related Accidents and Illnesses Continues to Increase, ILO and WHO join in call for Prevention Strategies Press Release.

Investopedia (2016). What is a Bonus. Retrieved on 24th August, 2017 from http://www.investopedia.com/terms/b/bonus.asp\#ixzz4IGiz5Fuc

Ippolito, Richard A. (1997). Pension Plans and Employee Performance. Chicago, IL: University of Chicago Press.

Jones, G.R. \& George, J. M., (2006). Contemporary Management, (4th ed). McGraw-Hill. Kogan Page: London.

Kanzunnudin, M. (2007), Effect of wages and supervision of employee productivity: A case Study on PT Tonga Tiur Son Zenith District Kragan. Fokus Ekonomi, 2(I), II-20.

Lake, S. (2000). Low Cost Strategies for Employee Retention: Compensation and Benefits Review. 32(4), 65-72.

Lake, S. (2000). Low Cost Strategies for Employee Retention: Compensation and Benefits Review. 32(4), 65-72.

Loeppke R, Taitel M, Haufle V, Parry T, Kessler R, \& Jinnett K. (2009). Health and Productivity as a business strategy: a multi-employer study. J Occup Environ Med. 2009;5 I:4I I-428.

Markham, Dow, \& McKee, (2002) „Disentangling the Wage-Productivity Relationship: Evidence from Select OECD Member Countries"e, International Advances in Economic Research, 8, 31423

Mathis, Robert L., and John H. Jackson. (2003). Human Resource Management. (I Ith ed). Mason, OH: Thomson/SouthWestern.

Mathis, Robert L., and John H. Jackson. (2003). Human Resource Management. (IIth ed). Mason, OH: Thomson/SouthWestern.

McNamara C., (2003). Field Guide to Leadership and Supervision for Nonprofit Staff. (2nd ed.). Amazon.

Milkovitch, G. and Newman, J. (2004). Compensation (8th edn). New York: McGraw-Hill.

Millea, N. (2002). Simplified Method of Measuring Productivity Identifies Opportunities for Increasing It. Industrial Engineering

Millea, N. (2006). Improving Productivity and Effectiveness. Prentice-Hall, Inc.

Mishra, S. \& Bhagat M. (2007). Principles for successful implementation of labour welfare activities. From police theory to functional theory.

Neil, Charness, (2000). "Can Acquired Knowledge Compensate for Age-Related Declines in Cognitive Efficiency?” Psychology and the Aging Revolution: How We Adapt to Longer Life. Washington, D.C.: American Psychological Association.

Oloke, O.C., Abiodun S. Oni A.S., Babalola,D.O., Ojelabi R.A (2017) Incentive Package, Employee's Productivity and Performance of Real Estate Firms in Nigeria. European Scientific Journal I3(I I)I857 - 788 I

Perrin, Towers, (2005). “The Business Case for Workers Age 50+: Planning for Tomorrow's Talent Needs in Today's Competitive Environment.” A report for AARP.

Pikiell, John, (2000). An RX for Detection and Prevention of Worker"s Comp Fraud. Employee Benefits News, November I, 34.72

Redmond,R E (20I0) A factor analytic study of job satisfaction items designed to measure Maslow need categories. Personnel Psychology, 24, 205-220.

Romanoff, K. (2008). What is the difference between a bonus and an Incentive? Retrieved on 25th August, 2017 from http://theperfectpayplan.typepad.com/the_salary_sage/2008/07/what-is-the-dif.html

Sajuyigbe, A. S., Olaoye Bosede .O and Adeyemi M.A (20I3) Impact of Reward on Employees Performance in a Selected Manufacturing Companies in Ibadan, Oyo State, Nigeria International Journal of Arts and Commerce. 2(2) pp27-32.

Scarth, W. (2002). Population Ageing, Productivity and Living Standards. In The Review of Economic Performance and Social Progress: Towards a Social Understanding of Productivity. A. Sharpe, F. St-Hilaire, and K. Banting, eds (pp. I45I56).

Shellengarger, Sue (200I). Work and Family, The Wall Street Journal, August 22, BI.

Surbhi, S. (2015). Differences between Salaries and Wages. Retrieved on 24th August, 2016 from .http://keydifferences.com/difference-between-salary-andwages.html\#ixzz4IGICT6Vu 
Torrington, Derek. Hall, Laura. Taylor, Stephen \& Atkinson Carol (2009), Fundamentals of Human Resource Management, (Ist ed). Pearson Education Limited.

Tyson S. (1999), "Human Resource Strategy: a process for Managing the contribution of HRM to organizational performance", in Schuler, R.S., Jackson, S.E. (ed), Strategic human resource management, pp.I I0-I23.

Whittington, J L and Evans, B (2005) General issues in management: the enduring impact of great ideas. Problems and Perspectives in Management, 2, I I4-I

Willing, Richard. (2000), Court Approves Forced Comp Time, USA Today, May 2, IB. 73.

Woodward, N., (2000), Benefiting from Adoption, HR Magazine, December, II9.

Wright D.W, Beard M.J, \& Edington D.W. (2002). Association of health risks with the cost of time away from work. J Occup Environ Med; 44:1126-II34.

Appendix

Section A: (Bio-Data)
I. Sex:
(a) Male (
(b) Female

2. Marital Status: (a) Single ( ), (b)Married ( ), (c) Divorced ( ), (d) Widowed, (e) Separated ( )

3. Age: (a) 2I-30years ( ),(b) 3I - 40 Years ( ),(c) 4I-50years ( ), (d) 5I-60 Years ( ), (e) 60years and Above ( )

4. Position/Status: (a) Top Level Management ( ) (b) Middle Level Management ( $\quad$ ) (c) Lower Level Management ( )

5. Educational Qualification: (a) SSCE/O'Level ( ), (b) ND/NCE ( ),(c)HND /B.Sc. ( ), (d) MBA/ M.Sc/ICAN/CIBN and Other ( )

6. Years in Service: (a)I-5years ( ), (b) 6-IOyears ( ), (c)I I - 20 years ( ), (d) 2I-30 years ( ), (e) 3 I and above ( Section B: Forms of Remuneration package

\begin{tabular}{|c|c|c|c|c|c|}
\hline & Forms of Remuneration package & Always & Occasionally & Sometimes & Never \\
\hline $\bar{I}$ & Security remuneration & & & & \\
\hline 2 & Overtime & & & & \\
\hline 3 & Annual leave & & & & \\
\hline 4 & Maternity leave & & & & \\
\hline 5 & Education and house allowance & & & & \\
\hline 6 & Health Protection & & & & \\
\hline 7 & Personnel Recognition & & & & \\
\hline
\end{tabular}

\section{Section C: Effect of Remuneration package on employees performance}

$\mathrm{I}=$ Disagree, $2=$ disagree, $3=$ neutral, $4=$ Agree, $5=$ Strongly Agree

\begin{tabular}{|c|c|c|c|c|c|c|}
\hline $\mathrm{S} / \mathrm{N}$ & Statement & $\begin{array}{l}\text { Strongly } \\
\text { Agree }\end{array}$ & Agree & Neutral & Disagree & $\begin{array}{l}\text { Strongly } \\
\text { Disagree }\end{array}$ \\
\hline 8 & $\begin{array}{l}\text { Constant remuneration payment enhances } \\
\text { employees' performance }\end{array}$ & & & & & \\
\hline 9 & $\begin{array}{l}\text { Overtime remuneration can be effective in } \\
\text { long -term motivation and productivity }\end{array}$ & & & & & \\
\hline I0 & $\begin{array}{l}\text { Pooling employee in a team with collective } \\
\text { goal increase productivity if you provide } \\
\text { worth-wild remuneration }\end{array}$ & & & & & \\
\hline II & $\begin{array}{l}\text { Employee morale improves if each one of } \\
\text { them is granted opportunities to reach a set } \\
\text { of goals. }\end{array}$ & & & & & \\
\hline
\end{tabular}


I2 Remuneration promotes morale and increase team cohesion

Section C: Relationship between improved remuneration and productivity in the Nigeria

$\mathrm{I}=$ Disagree, $2=$ Disagree, $3=$ Neutral, $4=$ Agree, $5=$ Strongly Agree

\begin{tabular}{|c|c|c|c|c|c|c|}
\hline $\mathrm{S} / \mathrm{N}$ & Statement & $\begin{array}{l}\text { Strongly } \\
\text { Agree }\end{array}$ & Agree & Neutral & Disagree & $\begin{array}{l}\text { Strongly } \\
\text { Disagree }\end{array}$ \\
\hline 13 & $\begin{array}{l}\text { High remuneration is capable of increasing } \\
\text { the self confidence of employees }\end{array}$ & & & & & \\
\hline $\mathrm{I} 4$ & $\begin{array}{l}\text { To motivate employee through remuneration, } \\
\text { it is necessary that remuneration is equitable } \\
\text { and externally competitive }\end{array}$ & & & & & \\
\hline I5 & $\begin{array}{l}\text { Employee remuneration package is a more } \\
\text { efficient motivating factor as it can easily } \\
\text { increase according to the proportion of work }\end{array}$ & & & & & \\
\hline 16 & $\begin{array}{l}\text { Quick payment of remuneration is assumed } \\
\text { to greatly influence employee productivity }\end{array}$ & & & & & \\
\hline 16 & $\begin{array}{l}\text { Enticing remuneration } \\
\text { employee dedication } \\
\text { productivity }\end{array}$ & & & & & \\
\hline 17 & $\begin{array}{l}\text { The type of remuneration and fringe benefit } \\
\text { made available to employee greatly } \\
\text { determines how motivated they would be } \\
\text { committed to duties }\end{array}$ & & & & & \\
\hline 18 & $\begin{array}{l}\text { For remuneration scheme to achieve desired } \\
\text { objective, that is, employee productivity, its } \\
\text { implementation must not frustrate the } \\
\text { employee. }\end{array}$ & & & & & \\
\hline
\end{tabular}

Copyrights

Copyright for this article is retained by the author(s), with first publication rights granted to the journal. This is an open-access article distributed under the terms and conditions of the Creative Commons Attribution license (http://creativecommons.org/licenses/by/4.0/). 